\title{
Research on the Reform and Innovation of Logistics Management under the Background of Electronic Commerce
}

\author{
Guanghua Li, Jingya Cao ${ }^{1, a}$ \\ ${ }^{1}$ Nanchang Institute of Science \& Technology, Nanchang City, Jiangxi Province, China, 330008 \\ a email:
}

Keywords: Electronic commerce, Logistics Management, Reform, Innovation

\begin{abstract}
Electronic commerce is an important form of economic and trade development in the future, and the modern e-commerce technology has a great impact on traditional logistics. Under the promotion of electronic commerce, modern logistics is constantly developing in the direction of informatization, networking, and multi function. Based on the author's study and practice experience, this paper firstly analyzes the characteristics of the modern logistics under the environment of e-commerce, and then discusses the problems of logistics management under the e-commerce environment, and finally puts forward the basic way of logistics management innovation under the e-commerce environment.
\end{abstract}

\section{Introduction}

In twenty-first Century, the overall development of information technology will push the world into the era of electronic commerce. Most logistics companies have to follow the trend, register their own web site, formulate the corresponding network development plan, gradually establish a network business system. As the third source of profit after the field of raw material resources and human resources, logistics provides a strong support for the continuous development of e-commerce. At the same time, e-commerce has brought opportunities for the development and improvement of the current logistics model.

\section{Characteristics of Modern Logistics under the Environment of Electronic Commerce}

Information. In the era of electronic commerce, information is the core. Information is not only reflected in the choice of goods and electronic payment, but also fully reflected in the whole process of logistics. In order to provide customers with the best logistics services, logistics system must have a good information processing and transmission system. Large logistics companies usually set up information processing centers to accept orders from all over the country. With the information processing center, they can do what the customer needs on the production, rather than the production that waits for customers to buy[1]. Through the information system, customers can clearly understand the exact time and location of the goods, making the consignee of the warehousing company, transport companies to prepare early and in the case of almost no stop, in time, quickly and accurately to reach the destination.

Network. Logistics network is mainly manifested in two aspects, on the one hand, the network of logistics information transmission and storage, on the other hand, the network of material flow in the order, production, transportation and so on. Internal network, external network and Internet 
constitute the logistics information network together. Logistics information network is a link between the enterprise and the upstream and downstream manufacturers and customers, and it is the basis of logistics informatization and network realization of logistics process.

Multi-function. With the development of electronic commerce, modern logistics has developed to the intensive development, which requires logistics enterprises not only to provide warehousing, transportation and other services, but also to carry out the distribution, distribution and processing services that can improve the circulation of value, and according to the needs of customers to provide other related services. Modern logistics develop to the multi-function, pursuit of a comprehensive, systematic and comprehensive effect, in order to make the logistics services to optimize.

Hommization. The hommization of logistics management means that the modern logistics organize and implement the logistics operation in order to meet the needs of the production, circulation and consumption of electronic commerce according to customer demand and production, circulation, consumption characteristics. The development of electronic commerce makes the demand changed from large to small, personalized and fast direction. Production activities of enterprises need to be carried out according to the actual needs of customers and the market, and in the production time is also showing a trend of rapid. The mode of logistics management is also developing to the direction of hommization, and the logistics management is full of vigor and vitality[2].

\section{The Problems of Logistics Management under the Environment of Electronic Commerce}

Logistics enterprises are small. At present, China's logistics enterprises are mainly small and medium sized enterprises, and the problems of lack of social logistics demand and shortage of professional logistics supply capacity exist together. Local blockade and monopoly of the industry form a barrier to the integration of resources and integration, and the logistics market is not standardized. Enterprise scale is small, and only in some ways, it realizes the electronic information. Enterprise is not mature enough in the use of network and information technology, and the information technology funds and human input is insufficient.

Logistics management professionals is shortage. In the era of electronic commerce, logistics management mainly needs the talent of macro management level, enterprise logistics management talent and logistics enterprise management personnel. Complex logistics talent is the person who is proficient in modern economic and trade, logistics, transportation, English, international trade and other fields of knowledge, and they have a very important role in the development of modern logistics. However, in all areas of the domestic logistics industry, it generally lacks complex logistics personnel, especially the third party logistics elite talent. In the logistics industry, there is little personnel mastering the modern logistics professional application technology.

The e-commerce logistics distribution system is not perfect. Information flow is built on the basis of written, so that it can provide timely logistics information, which not only reduces the level of logistics services, but also inhibits the development of China's logistics industry, affects the popularization and application of electronic commerce, becoming a bottleneck restricting the development of e-commerce logistics. China's logistics standardization degree is low, the lacking a unified standard. Some enterprises adopt the European and American Standard, and some enterprises adopt the Japanese standard, which causes the inconvenience of the connection of the logistics, and affects the efficiency of logistics operations to a certain extent, restricting the development of e-commerce in our country. 
The government and enterprises are not paid enough attention to the logistics of electronic commerce. At present, the electronic commerce logistics market competition mechanism and management laws and regulations are not perfect, the market entry and exit, and there is not a uniform legal provisions for the entry, exit and the competition rules. The lack of effective constraint mechanism of social e-commerce logistics, results in serious unfair competition. Logistics development involves many aspects, such as infrastructure, technical equipment, industrial policy, investment and financing, etc., and these aspects are managed by different government departments. Due to the relevant functional departments of modern logistics lack enough understanding, logistics market and industry management are classified according to departments, regions and industries, causing the problem of logistics management segmentation and repeated construction.

\section{The Basic Way of Logistics Management Innovation under the Electronic Commerce Environment}

Gradually to strengthen government guidance and industry legislation. China's e-commerce logistics has just started, and lots of aspects are not perfect, mature e-commerce logistics system has not been established, the corresponding laws and regulations are not perfect, which is very disadvantageous to the development of the modern logistics[3]. The government should support the development of e-commerce logistics enterprises in terms of policies and funds, formulate correct policies and industry development strategy, strengthen the development of e-commerce network security technology research and the development of laws and regulations. For example, as soon as possible to develop logistics information technology standards and information resources standards, to establish the exchange and sharing mechanism of logistics information collection, processing and service; To construct e-commerce logistics distribution system in order to promote the development of e-commerce logistics industry; Actively to promote enterprise logistics management information in order to promote the wide use of information technology, and guide enterprises to increase investment in e-commerce logistics industry; Effectively to integrate the business flow, logistics, capital flow and information flow, forming a trading platform for the national and global markets.

Based on the experience of developed countries to improve the planning and control system of e-commerce logistics activities. The United States built a logistics information platform based on the Internet, have mature standardized logistics software, using information technology to integrate logistics information, develop logistics solutions, optimize the various stages of the process, so that the logistics management more scientific, standardized, can quickly and accurately operate, improve efficiency and increase efficiency. For example, Wal-Mart Store Inc achieves an effective logistics cost control through the integration of information flow on the logistics and capital flow, optimization and timely processing. Therefore, in order to realize the innovation of logistics management, logistics enterprises in our country must put the service quality and customer demand in the first place, which requires enterprises in accordance with the flexibility of the market and customer oriented, the development of strategic planning of logistics activities, and predict the possible problems in advance to take preventive measures.

Pay more attention to the cultivation of professional talents of electronic commerce and logistics management. E-commerce logistics has put forward higher requirements for the quality of enterprise logistics personnel. High quality logistics management talent is an important prerequisite to ensure customer service quality, logistics operation efficiency and competitiveness of enterprises. In personnel training, it can rely on the government, colleges and universities, research institutes to train the e-commerce logistics personnel, making the logistics frontline staff and management 
update logistics professional knowledge through training. Logistics enterprises can also study abroad advanced technology and management concept through the introduction of advanced technology and outstanding talents. Learning and introducing modern logistics management concepts and management methods, its purpose is to reverse the backward situation in the country.

Vigorously develop the logistics finance. Logistics finance plays an important role in the development of modern logistics industry. First, it is the financing channels of logistics enterprises and the upper and lower reaches of the enterprise and the enhancement of financing ability can bring development opportunities for all parties in the logistics chain. Second, to improve the efficiency of the use of funds, under the circumstances of financial strain, shorten the period of account receivable of the upstream enterprise, make an inventory of raw materials and finished products of the downstream enterprises temporarily idle funds. Third is to reduce the financial risk of logistics enterprises; Fourth is to improve the service capacity of logistics companies, to enhance the cohesion of the logistics company and the upstream and downstream enterprises[4]. Of course, carrying out the logistics finance needs to carefully select customers, carefully select and keep the pledge, pay attention to debt default and capital risk, cooperate with enterprises to establish a total management account to achieve a effective supervision for the capital flows.

To enhance the role of promoting the development of international logistics. At present, affected by the international economic situation, the development speed of international logistics is slowing down, and in sharp contrast, e-commerce logistics has maintained a rapid growth trend, became the inevitable trend of international logistics development in the future, and the average annual growth rate of the international logistics based on e-commerce has reached more than $30 \%$. At the same time, some of the contradictions and problems that restricting the development of international logistics are gradually emerging. For example, the social and business requirement to further improve the efficiency of customs clearance, reduce the logistics cost, solve the issues of electricity supplier trade settlement and tax rebates[5]. Therefore, it is of great significance to carry out International logistics e-commerce pilot.

\section{Acknowledgments}

Project fund:

General project of science and technology program of Jiangxi Provincial Education Department, 2015 (GJJ151246).

General project of science and technology project of Nanchang Institute of Science \& Technology, 2015 (GJKJ-15-60).

\section{References}

[1] Li Deku. Logistics management innovation in e-commerce environment [J]. China's circulation economy, 2013,08:39-43.

[2] Rao Shaolun. E-commerce logistics system optimization of [J]. logistics technology, 2014,01:175-177.

[3] Wang Juanjuan. Analysis of logistics development in the era of electronic commerce [J]. China's circulation economy, 2014,03:54-59.

[4] Liang Shuhui, Zhou Yongsheng. E-commerce logistics development present situation and countermeasure research of [J]. China market, 2015,12:164-168.

[5] Dong Linfei. Research on the concept and model of e-commerce logistics [J]. Journal of Chongqing University of Science and Technology (SOCIAL SCIENCE EDITION), 2011,20:74-75+87. 